\title{
Ernst Troeltsch and Mysticism
}

\author{
Arie L. Molendijk \\ Faculty of Theology and Religious Studies, University of Groningen \\ Oude Boteringestraat 38, 9712 GK Groningen, The Netherlands \\ a.l.molendijk@rug.nl; https://www.ariemolendijk.nl/
}

\begin{abstract}
Although the 'mystical' character of Ernst Troeltsch's theological programme is controversial, the fact that 'mysticism' played an eminent role in his analysis of modern Christianity can hardly be denied. This article first spells out the different aspects of Troeltsch's concept of mysticism (Mystik) against the background of contemporary theological and religious developments. On the one hand, the highly critical discourse on mysticism of the dominant Ritschl School is highlighted and on the other hand, the proliferation of all sorts of 'mystical' religiosity in Germany around 1900 is discussed. Secondly, it is shown that Troeltsch distanced himself to a large extent from the critics of mysticism. In fact, he takes the concept of mysticism to denote a typical, modern, individualistic form of piety and theology. Thirdly, attention is given to the fact that Troeltsch adopts the mystical terminology to describe his own position and uses it to develop his ecclesiology. Fourthly, Troeltsch's view of the relationship between (individualist) mysticism and ethics is discussed. In his view, mysticism does not imply quietism, but an active engagement in church and worldly matters. All in all, this contribution underscores the importance of Christian mysticism for Troeltsch's personal belief and piety as well as for his 'mystical' conceptualization of religion.
\end{abstract}

\section{Keywords}

mysticism - Ernst Troeltsch - Albrecht Ritschl - ecclesiology - ethics 
The well-known statement by Harnack that anyone who is a mystic without becoming a Catholic is a dilettante, I cannot feel in any sense right.

TROELTSCH ${ }^{1}$

The manner in which Protestant theologian, philosopher and sociologist of religion Ernst Troeltsch $\left(1865^{-1923}\right)$ related to the phenomenon and concept of mysticism is a matter of controversy even today. It not only concerns his famous typology of "church, sects, mysticism", but most notably the question whether his thought can be classified as mystical or spiritual. ${ }^{2}$ The three types "church, sects, mysticism" outline basic forms of community formation in Christianity; however, scholars immediately begged the question of whether the individualist mystical type represents a separate social form. Martin Buber reacted to one of Troeltsch's lectures with the statement that mysticism, in his opinion, was a "religious solipsism". ${ }^{3}$ What is more, Troeltsch referred to the foundations of his own theology by the controversial term of 'mysticism'. "Personally, I take inspiration from the mystics who are the only Civitas Dei," he wrote to his friend Paul Wernle on 25 November $1915 .{ }^{4}$ Weren't these peculiar ideas for a Protestant theologian who otherwise decidedly emphasized the value of institutions?

1 Troeltsch 1912a and Troeltsch 1931, p. 860A; p. 964, n. 471.

2 This article is the English translation of the revised version of Molendijk 1999; cf. also Molendijk 1996, 2018. Here I refer to Troeltsch's Gesammelte Schriften (4 volumes, 1912-1925) and briefly to the texts edited in the critical complete edition (Kritische Gesamtausgabe, edited by F.W. Graf at De Gruyter publishers; e.g. Troeltsch KGA VI, pp. 396-398).

3 The suggestion that the term "mysticism" refers to a social configuration of Christianity already alienated the audience at its first presentation at the first German Sociologists' Conference (Deutscher Soziologentag) in October 1910. Martin Buber criticized Troeltsch's conception and proposed that mysticism was a psychological category that in itself negates all community; cf. Simmel 1911, pp. 205 et seq. Cf. Molendijk 1996, pp. 63-66; Zachhuber 2013.

4 Quoted from Troeltsch, KGA, vol. 21, p. 483; "A deep transformation is necessary, but it is the preference of selfishness in the divine element that we carry in ourselves and that is only ignited by all 'revelation'. In short, I am drawing nearer to love in the style of Seb. Frank" [Eine tiefe Wandelung ist nötig, aber sie ist die Vorziehung der Eigensucht in das göttliche Element, das wir in uns tragen und das von aller 'Offenbarung' nur entzündet wird. Kurz ich rücke der Liebe im Stile von Seb. Frank immer näher] (letter from 18 September 1918). 
It may not be a coincidence that a Catholic theologian (Karl-Ernst Apfelbacher) highlighted the importance of mysticism - understood in whatever way - in Troeltsch's thought. Likewise, it probably is no coincidence that his thesis regarding Troeltsch has been attacked so much in this respect. In hindsight, he wrote that while drafting it, he "hadn't really been aware" that "by taking recourse to the mystical-spiritualist tradition and my thesis that Troeltsch had to be understood mainly from this tradition, I was formulating and arguing a particularly exciting and novel thesis." ${ }^{5}$ Two prominent Troeltsch researchers with Protestant backgrounds - Hartmut Ruddies and Walter E. Wyman - criticized him and emphasized Troeltsch's distance to mysticism in their reviews. ${ }^{6}$ In conclusion, Ruddies wrote:

But what substantially distinguishes Troeltsch from a mystical position is the fact that his speaking of the participation of the human spirit in the divine spirit on the one hand does not intend to compete with universal historical knowledge, i.e. explicitly does not base itself in a knowledge from an epiphany; and on the other hand what he says about the unity of the divine and the human spirit precisely does not lose sight of its line of origin which harks back to Christian revelation, even though it is not possible to identify this point by point in its written manifestation. ${ }^{7}$

Important though these remarks are, such criticism is ultimately based in a narrowing of the concept of mysticism, which is historically unjustifiable. One might contest whether the term 'mysticism' is the most appropriate one to describe Troeltsch's position; however, Ruddies' remarks are insufficient to clearly differentiate Troeltsch's approach from mystical conceptions.

According to Apfelbacher, the opposition against the mystical-spiritualist tradition as such may actually explain the failed reception of Troeltsch in academic theology. ${ }^{8}$ This is a strong thesis, but probably it is true that our view of his theology becomes distorted if its proximity to mysticism is disregarded. This is not to say that Troeltsch himself had an untroubled relation to mysticism by implication. In his oeuvre, we can find explicitly negative statements: that mysticism was a "phenomenon of paralysis" and a "product of disintegration". 9 There also is some uncertainty regarding the question whether mysticism was

5 Apfelbacher 1978; idem, 1984, p. 118.

6 Ruddies 1983; Wyman 1980, p. 355: "his unfortunate thesis regarding Troeltsch's 'mysticism”".

7 Ruddies 1983, pp. 105 et seq. Emphases are always from the original.

8 Apfelbacher 1978, p. 174.

9 Troeltsch 1913 [1894], p. 270. 
the "primordial phenomenon of all religion"10 or on the contrary, a "secondary" manifestation. Over and beyond that, Troeltsch talks about the "mystical type", regarding which some have doubted whether it is at all connected with the general use of the concept of mysticism. ${ }^{11}$

Troeltsch's contradictory statements on mysticism have to be understood against the background of the complex situation of the "landscape of mysticism" around 1900, and the associated ambiguous use of the concept of mysticism. Troeltsch tried to differentiate here, but the distinctions he himself made are not always consistent. Only once the layers or dimensions of his conception of mysticism are clearly differentiated we may hope to bring the coherence of Troeltsch's conception to light and to fathom the significance of his placing himself in the line of tradition of mysticism and spiritualism. I also would like to refine Apfelbacher's interpretation, which focuses on Troeltsch's personal religious-mystical position, by pointing out the theoretical function of mysticism in his work. My thesis is that mysticism for Troeltsch not only signifies a practice of piety, but also has a theoretical significance that is fundamental for his philosophy of religion and his theology.

The aim of the present contribution is to set out Troeltsch's concept of mysticism in its various nuances and to demonstrate how deeply Troeltsch's position is rooted in the tradition he himself called "mystical". This will be done following a number of paradigmatic questions.

- First I will sketch the contemporary background against which Troeltsch's conception of mysticism needs to be situated (I).

- Then I will discuss (a) Troeltsch's search for the historical location of a modern, "mystical" Christian form of religion, and (b) some fundamental differentiations within his concept of mysticism (III).

- Third I will use the ecclesiology of Troeltsch to discuss the tension between mystical individualism and tradition-bound intersubjectivity and institutional structures (IV).

- Finally there will be some concluding remarks on the issue of "mysticism and ethics" (v).

2

There was so much talk of mysticism in turn-of-the-century Germany that people asked whether it still meant anything in particular: "People just use the

\footnotetext{
$10 \quad$ Troeltsch 1913 [1909], p. 493.

11 Rendtorff 1993, esp. p. 185.
} 
word in a sense that may signify anything that would otherwise be hard to define or specify, which however for this reason often clarifies nothing really."12 There is no doubt this complaint is to a large extent justified. For understanding the situation Troeltsch found himself in when he chose the term mysticism to outline a form of Christianity that lent itself to modernity, two considerations are important: first the boom of "mysticism" in Germany around 19oo, second the theological criticism of mysticism on the part of the influential Ritschl School. Both will need to be discussed briefly below.

The landscape of mysticism was perceived to be broad at the time. There was talk of a wave of mysticism, pantheism, occultism etc. In the philosophy of life (Henri Bergson), in literature (Rainer Maria Rilke), and in religiosity within and outside the church, we can discern a search for immediacy. I will not venture to summarize these currents, ${ }^{13}$ but instead follow Walther Hoffmann's contribution on the issue of "new mysticism" in the first edition of the encyclopaedia "Religion in Geschichte und Gegenwart" (Religion Past and Present, 1909-1913) in order to point out some important aspects. What is striking at first glance is that the flourishing of mysticism was perceived as a novel development. In the article about mysticism, "new mysticism" is given its own section, and Hoffmann saw "this new movement" as "quite independent": It is "by no means a direct continuation of old mysticism."14 He says it replaced the authority of religion with inner experience and differed from old mysticism in its orientation towards the sensual world, and thus lost sight of the transcendence of God. Here, God had become "artistically romanticized sensuality", and religion no more than pure sentiment. ${ }^{15}$ This seems to amount to a rather critical evaluation of this new phenomenon. However, what follows in Hoffmann's presentation is a counterpoint: insofar as new mysticism - for instance in the oeuvres of Johannes Müller, Albert Kalthoff, or Arthur Bonus guided its adherents back to a transcendental God, it had to be seen in a more positive light.

This nuanced appraisal of this new, free-floating religiosity can also be found in Troeltsch. While he was unable to believe in the future of "this kind of religion of the immanence of the individual spirit within the All, apart from all fellowship, practice of worship, and basis in history", ${ }^{16}$ he nevertheless

\footnotetext{
12 Fresenius 1912, introduction.

13 Cf. e.g. Nipperdey 1988; Hübinger 1994. Troeltsch, too, contributed considerably to this subject; cf. Troeltsch 1925 [1921].

14 Hoffmann 1913, p. 6o8; cf. Scholz 1914, p. 1929.

15 Hoffmann 1913, p. 610.

16 Troeltsch 1912a and Troeltsch 1931, p. 933, n. 504 and p. 984, n. 504.
} 
endeavoured to elaborate the "moment of truth" of such views. ${ }^{17}$ In these new religious movements, he saw the potential to revitalize the "yearning for the absolute" which provided a counterbalance against the progressive rationalization and mechanization of the world. ${ }^{18}$ The criticism of modernity this new religiosity represented was an important reason for Troeltsch's positive assessment. He was however sceptical of its potential of becoming a culturally influential organisation, and for instance distanced himself from the cultural and religious policy of publisher Eugen Diederichs who attempted to promote and organize the mystical forms of religion, although he appreciated Diederich's work "on a spiritual regeneration". ${ }^{19}$

The perception and evaluation of the nascent religiosity of "experience" and its criticism of culture and church was a neuralgic point in liberal circles, too. Thus the church historian Paul Wernle criticized the breadth of Troeltsch's conception of mysticism:

The mysticism of the ancients could decidedly not be had as cheaply as the circle of readers of Diederich's presently believes. You had it for the price of killing off your own will, [...] of solitary immersion in God whose presence can only become sensed on the ruins of one's own self. It is almost ludicrous to liken our modern fashionable religion with it. ${ }^{20}$

With the concept of mysticism, Troeltsch had, amongst others, aimed to include the modern tendency of internalization and subjectification of the religious; non-Christian movements, therefore, could be included under this denominator. Troeltsch conceded that in many cases, the connections between

17 Troeltsch 1913 [1913], p. 816A. Troeltsch 1991 [1913], p. 55. The original footnote was omitted in the translation. Troeltsch here refers to Arthur Bonus; cf. König 2018.

18 Cf. Troeltsch 1925 [1913], p. 645.

19 Letter of Troeltsch to Eugen Diederichs dated 10 June 1915, quoted from: Troeltsch, KGA, vol. 21, pp. 108 et seq.: "I admire your idealism and your indefatigable work on a spiritual regeneration. And you have already achieved a lot in this regard with your publishing house. But there can hardly be an organization for such things. This would have to be a church or an order, a cultural salvation army. The purely theoretical work and the organization of literature have their limitations [... I] place more hope in good books from your publishing house $[\ldots]$ than in your organization of Neo-Idealism." [Ich bewundre Ihren Idealismus u Ihre nie ermüdende Arbeit an einer geistigen Regeneration. Sie haben ja auch schon durch Ihren Verlag in dieser Richtung vieles ausgerichtet. Eine Organisation aber giebt es für solche Sachen schwerlich. Das müßte schon eine Kirche oder ein Orden, eine kulturelle Heilsarmee werden. Die rein gedankliche Arbeit u die Organisation der Literatur hat ihre Grenzen. [... Ich] setze mehr Hoffnungen auf gute Bücher Ihres Verlages [...] als auf Ihre Organisation des Neu-Idealismus.] Cf. Hübinger 1987.

Wernle 1913, pp. 77 et seq. 
mysticism and Christian tradition "were thoroughly confused or even broken". 21 For him personally, the connection to Christian tradition was fundamental; from a sociological point of view, however, mysticism within and outside of Christianity belong together as phenomena of religious individualization. Differences like the one between mysticism proper and improper comprise connotations that Troeltsch wanted to avoid.

We have now come to the contemporary evaluation of mysticism. The status of mysticism at the time was heavily contested, mainly under the impact of Albrecht Ritschl. The influential Ritschl School simply rejected mysticism: in mysticism, they claimed, Christian substance was lost. In the context of his attempt to clearly delimit the inheritance of Reformation from medieval mystic theologians like Bernard de Clairvaux, Ritschl had introduced the following influential definition of mysticism, which was

primarily the devotion guided by the Areopagite concept of God in which the transcendence of all mediation until complete absorption of the particular consciousness into the indiscriminate essence of God is aspired to as something attainable already in the mundane present. ${ }^{22}$

Here, mysticism - because of its supposed skipping of the historical salvific action of the Gospel and the Church - means the end of all (Protestant) Christianness, and a slippery slope into Neo-Platonism and Catholicism. ${ }^{23}$ This view has had its followers, amongst others in the oeuvres of Wilhelm Herrmann and Adolf von Harnack. ${ }^{24}$ Troeltsch highlighted this

21 Troeltsch 1912a and Troeltsch 1931, p. 932 and p. 795 (translation corrected).

22 Ritschl 1870, p. 113 (emphasis in the original).

23 Cf. Ritschl 1880-1886, vol. I, p. 28: "Mysticism of course has the reputation of being particularly closely related to the Lutheran reformation. However, it rather is no more than the pronounced level of Catholic piety [...] In fact, mysticism in the Christian church is a layer of Neoplatonism." [Nun steht ja freilich die Mystik in dem Rufe einer besonders nahen Verwandtschaft mit der lutherischen Reformation. Indessen ist sie vielmehr nur die prononcirte Stufe der katholischen Frömmigkeit [...]. Eigentlich ist ja die Mystik in der christlichen Kirche ein Absenker des Neuplatonismus]; cf. Ritschl 1880-1886, vol. I., p. 35 .

24 Herrmann 1908, p. 21: "If today, even protestant theologians suppose themselves to be unable to part from mysticism, they really admit they cannot part from Catholic Christendom." [Wenn nun auch evangelische Theologen meinen, sich von der Mystik nicht scheiden zu können, so geben sie in Wahrheit zu, daß sie sich von dem katholischen Christentum nicht scheiden können]; Harnack 1910, vol. 3, pp. 435 et seq.: "Well - no protestant Christian would ever have entertained the thought of confusing the joy in the active inner life which Catholic Christianity possessed in the centuries before Reformation with his full approval of it, if he - this needs to be said - had realized what Protestant 
astonishing equation of Catholicism, monasticism, sectarianism, mysticism, and Enlightenment, in which every member at the same time represents the unhealthiness of the other one, and over against which there only remains Ritschl's moderately rationalist but still essentially positively supernatural Lutheran ecclesiasticism, which is adapted to a modern popular ethic. ${ }^{25}$

This dismissal of mysticism, however, had been controversial before. The earlier debate, in which Neo-Lutheran Chr. Ernst Luthardt had still defended the relative value of mysticism against Ritschl, ${ }^{26}$ will not be pursued here. ${ }^{27}$

What is remarkable, however, is that in this context mysticism is evoked when the inheritance of Reformation is discussed. Thus, what is at stake is explicitly not novel developments like Neo-Mysticism, but a true account of the genesis of Protestantism. As Troeltsch keenly remarked, for most Lutherans, the limit of acceptance of mysticism was reached when it had an anticlerical impact. The theological struggle around mysticism in the last third of the 19th century, therefore, was essentially a battle for ecclesiology and the tenability of the traditional regional church regimen. Outside the theological discussion, the importance of mysticism for Reformation was acknowledged more

faith is. The inability to penetrate it generates the desire for mysticism [...] A mystic who doesn't convert to Catholicism is a dilettante." [Nun - kein evangelischer Christ wäre wohl je auf den Gedanken verfallen, die Freude an dem regen innerlichen Leben, welches das katholische Christentum in den Jahrhunderten vor der Reformation aufweist, mit der vollen Zustimmung zu demselben zu verwechseln, wenn er sich - man muß es leider sagen - klar gemacht hätte, was evangelischer Glaube ist. Das Unvermögen zu diesem vorzudringen, erzeugt die Begehrlichkeit nach der Mystik [...]. [E]in Mystiker, der nicht Katholik wird, ist ein Dilettant.]

25 Troeltsch 1912a and Troeltsch 1931, p. 874, n. 479, and p. 966, n. 479; cf. p. 86o, n. 471, p. 869, n. 476 and p. 964 , n. 471 , p. 965 , n. 476 .

26 Luthardt, pp. 248 et seq.; cf. Reischle 1886, p. 6.

27 Important references in this respect are the articles "mysticism" [Mystik] and "theology, mystical" [Theologie, mystische] in the different editions of the Realenzyklopädie für protestantische Theologie und Kirche (established by G.J. Herzog). Thus J.P. Lange (RE', vol. 10, Gotha 1858, p. 152-164) was still able to write in passing: "The inner vibrancy of religion is always mysticism." (p. 153). W. Preger emphasized the difference between healthy and "pathological" mysticism (RE ${ }^{2}$, vol. 15, Leipzig 1885, p. 487-504). S.M. Deutsch (RE3 vol. 19, Leipzig 1907, p. 631-644) underlined that even a revealed religion will not be able to manage without experience (mysticism), and that in contemporary theology and literature (Collenbusch, Jung Stilling, Lavater, Anna Schlatter, Matthias Claudius; under the keyword "theosophy", the following names are enumerated: Oetinger, Swedenborg, Philipp Matthäus Hahn and Michael Hahn), mysticism played a not insignificant role. The anonymous article "mysticism, Christian" [Mystik, christliche] in the Kirchliches Handlexikon, vol. 4. Leipzig 1894, p. 717-720, also criticized Ritschl. 
openly. ${ }^{28}$ In addition, the Schleiermacher revival at the end of the 19th century raised the question if Schleiermacher, namely in the "Speeches", may not have argued for a 'mystical' understanding of religion. ${ }^{29}$ Wilhelm Dilthey for instance wrote, referring to Ritschl:

Schleiermacher's recognition of the importance of mysticism in religion was superseded by an ahistorical hatred against the mystical in religion. The importance of religious experience in the history of religious creation was unfathomable to this sober head. ${ }^{30}$

By combating mysticism, Ritschl - according to Dilthey - also casts aside Schleiermacher's foundation of a general study of religion. In this view, accordingly, mysticism also functions as a key concept of religious studies.

In the first quarter of the 2oth century, mysticism became even more of a polemical concept. On the orthodox side, there was talk of mysticism as a sign of "the psychosis of a diseased soul of the nation".31 Through its connection with novel forms of mysticism, liberal theology became increasingly discredited. In Emil Brunner's book "Die Mystik und das Wort" [Mysticism and the Word], Schleiermacher's programme of a "combination of a philosophy of immanence (or mysticism) and Christian faith" was exposed as a "self-delusion". 32 Here, mysticism represents a false theology which is not based on the foundations of the word of Revelation. The "mystical" character of Schleiermacher's theology, according to Brunner, and incidentally also Karl Barth, thus proved its illegitimacy. ${ }^{33}$ Here, an academic use of the concept of mysticism within re-

28 Windelband 1904, vol I. p. 32; idem, 1980, pp. 312 et seq. On the contemporary form of mysticism, cf. Windelband 1924 [1910]; in it, he saw the "switch from rationalism to irrationalism", which he disapproved of (p. 291).

29 Cf. Schleiermacher 1991 [1899], p. 62 (comment): "Schleiermachers Mystik!" In his introduction, Otto situated the "Speeches" within the romantic tradition and also underscored the connection to the "newly stirring mysticism": "Emerging from their circle [i.e. the young romantic school, ALM] and its atmosphere, it [the text, ALM] is nothing less than a programme of the former in its conception of nature and history, in its struggle against the culture of the intellect and the 'philistines' of rationalism in state, church, school, society, in its tendency towards the imaginative, the profound, to foreboding and the mystical ..." (p. 8).

$30 \quad$ Dilthey 1962 [1911], pp. 300 et seq.

31 Kirchliches Jahrbuch 1921, p. 343, quoted from Maaß 1972, p. 130.

32 Brunner 1928, p. 11.

33 Barth 1978, p. 410: "Schleiermacher's theology [...] uses the pretext of Christian theology to strike up a song of triumph of man, simultaneously celebrating his mystical union with God and his cultural activity, and in this it fails and has to fail"; [Schleiermachers Theologie [...] will [...] unter dem Vorwand christlicher Theologie ein Triumphlied des 
ligious studies was more and more superseded by a theological-positional one. Ritschl's linking of mysticism and Catholicism has had long repercussions in the Protestant field. Barth's late devaluation of Troeltsch's doctrine in 1962 - "It was enough to turn you into a Catholic" ${ }^{34}$ - is only one more example. ${ }^{35}$

The subject of mysticism is always present in Troeltsch's oeuvre: in the early contributions to the "Zeitschrift für Theologie und Kirche" [Journal of Theology and Church], in his opus magnum on social doctrines, and in his late work on the history of philosophy. Obviously, this doesn't mean that it always concerns the same things. In this section, we will demonstrate how Troeltsch further defines mysticism with a historical as well as systematic purpose. First, we will describe the role of mysticism in Troeltsch's historical search for those currents and elements from tradition that provided the foundations for a modern Christianity (a). Second, his understanding of mysticism needs to be discussed in a systematic sense. The distinctions he introduced will also serve to explain his contradictory judgments regarding mysticism (b).

(a) In his early work, the concept of "mysticism" mainly served as a key concept for a specifically modern ${ }^{36}$ philosophical theory of religion, which regarded Christianity as a specific expression of religion as a whole. Troeltsch extensively described the genesis of this modern concept of religion, and thus of modern, Western religious studies and theology, and also permanently refined and modified his own conception regarding it, until he finally arrived at the type of mysticism. This journey of discovery was also a search for the roots of a form of religiosity appropriate for the modern age.

In his studies from the years around $1900^{37}$ he keeps referring to two important "heirlooms" which are important to Modernity: on the one hand to the categories necessary for a scholarly account of religion, and on the other hand to the practical-religious movements which introduced subjectification and individualization. Troeltsch situates these movements of internalization and

Menschen anstimmen, seine mystische Vereinigung mit Gott und seine Kulturtätigkeit gleichzeitig feiern, und daran scheitert sie und muß sie scheitern]; cf. Maaß 1972, p. 201; Klimek 1990, pp. 242 et seq., p. 251.

34 Barth 1962, p. 427 [Es war zum Katholischwerden].

35 On the importance of the concept of mysticism in the German-language protestant discussion of the 2oth century, see Elsas 1994.

36 Cf. Troeltsch 1922 [1906/21909], p. 618 (KGA VII, p. 332).

37 Cf. Troeltsch 1902 (KGA I, pp. 898-923); idem. 1903 (KGA VI, pp. 69-95). 
turning away from the church in the most diverse groups and individuals "in the Catholic mystics and Jansenists no less than in the English Puritans and Quakers, the Reformed and Lutheran Pietists and all sorts of new particular groups." ${ }^{38}$ In his sweeping studies on "Protestantisches Christentum und Kirche in der Neuzeit" (Protestant Christianity and Church in the Modern Age, 1906, ${ }^{2}$ 1909) and "Die Bedeutung des Protestantismus für die Entstehung der modernen Welt" (The Importance of Protestantism in the Development of the Modern World, 1906, ${ }^{2} 1911$ ), he focuses even more on Protestantism and emphasizes the contribution of the Anabaptists and spiritual reformers to the modern age. ${ }^{39}$ But it transpires that this view is too indiscriminate; therefore, it is corrected in the "Social Doctrines" (1912). While, he proposes, the importance of these two groups for the development of the modern world was considerable, it would be an entirely erroneous idea to treat them "as if in essentials both [Anabaptists and spiritual reformers] were the same."40

Only after he had elaborated the typology of the Christian-religious types of community formation "church, sect, mysticism", and in particular the type of mysticism around 1910, he conceptualized the basic difference between Anabaptism and spiritual reformism. In the second edition of "Protestantisches Christentum und Kirche in der Neuzeit" (1909), still, in which Troeltsch first introduced the dualism "Church-sect", which he had first used around 1908, the spiritual reformers were subsumed in the sect type..$^{41}$ Even though he already differentiated between legality, holy community, late baptism on the one hand, and inwardness, spiritual freedom and subjectification of religion on the other hand, ${ }^{42}$ Troeltsch still ascribed both ascetic legality and religious subjectivism to the sect character. The sects, and Anabaptism in particular, were thus - somewhat under the influence of Max Weber's views, who strongly

38 Troeltsch 1902, p. 98 (KGA I, p. 903).

39 Troeltsch 1922 [ $\left.{ }^{2} 1909\right]$, pp. 504-516; idem. 1911, pp. 24-28 (KGA VIII, pp. 225-228) and Troeltsch 1911/1912 \& 1958, pp. 43-52.

40 "Soziallehren" has been translated here as "Social Doctrines", whereas the original translation has "Social Teachings". Troeltsch 1912a and Troeltsch 1931, p. 848 and p. 729. Troeltsch more or less concedes that he himself had made this mistake; cf. p. 872, n. 478 and pp. 965 et seq., n. 478 (translation corrected): "Yet at that time I did not recognize sufficiently the difference between the Baptist movement and Spiritualismus, in simply ascribing the opposite positions both to the Anabaptist movement" [see his speech about the separation of state and church, Troeltsch 1907a, ALM ]; cf. p. 80o, n. 440, p. 826, n. 458, and Troeltsch 1931, pp. 949 et seq., n. 440 and p. 956, n. $45^{8}$.

Troeltsch ${ }^{2} 1922$ [1909], pp. 506 et seq., pp. 514 et seq. (KGA VII, pp. 178 et seq., pp. 189-192). On the genesis of the types, cf. Molendijk 1996.

Troeltsch ${ }^{2} 1922$ [1909], p. 512 (KGA VII, p. 186: addition as compared to the first edition). 
emphasized the affinity of the sects to Modernity ${ }^{43}$ - regarded as the modern religious movements par excellence, while in the "Social Doctrines" the mystical type was represented as the most modern, most individualized social form of Christianity. Only the discovery of the mystical type enabled Troeltsch to understand the individualization and subjectification of religion, and - in connection with it - the demand for freedom of conscience (of inner-religious tolerance) as the decisive characteristics of a modern Protestantism. This is in fact an amendment of Max Weber's views. ${ }^{44}$

The study of spiritualism (in comparison with Anabaptism) formed the context of the discovery of mysticism as an independent type. In a letter to the historian Konrad Burdach dated 19 December 1918, Troeltsch explained that the former's research had taught him "to understand the whole breadth and depth of this movement, from which vantage point only the projections back in time became intelligible." 45 The thesis of the "Social Doctrines" is that mysticism only became a distinct social form of Christianity in spiritualism, which is why Troeltsch is able to use the terms "mysticism" and "spiritualism" interchangeably in this context. Only at the beginning of the modern age, the (mystical) internalization and subjectification of (Christian) religion becomes more and more independent and a force outside the church, even at times opposing it.

(b) Troeltsch only succeeded in giving the basis of his own theology and philosophy of religion a historically precise dimension after a long time. Thus we need to distinguish between the - systematic - significance of the concept of mysticism in the context of a modern, adequate theory and philosophy of religion, and the - historical - significance of the mystical tradition for a modern Christianity. Troeltsch's essential point of view was already recognizable at an early stage. In his 1895 essay on the independence of religion, mysticism already served as a basic category of the theory of religion. Here, Troeltsch distinguished between a psychological and a historical approach of religion. From a psychological point of view, religion, according to Troeltsch, is essentially an experience, and insofar, the essence of religion is identified as mysticism - as

\footnotetext{
43 Cf. Weber 1906 \& 1906/1985; completely revised and extended as Weber 1988a [1920]. Cf. Graf 1995, pp. 212-215.

44 Cf. Troeltsch 1912a and Troeltsch 1931, p. 958, n. 512 and p. 989, n. 512: "I believe [...] that through my presentation of the sects, and especially in the clear distinction between mysticism and the sect-type, I have in some particulars made Weber's idea clearer, and also that through the manifestation of the sectarian elements in primitive Calvinism I have made the fusion of Calvinism with the sect-type more intelligible".

Quoted from Burdach 1934, p. 486; cf. Troeltsch 1925 [1922], p. 12.
} 
the "limitation of the religious event to itself". ${ }^{46}$ In this, however, it is important not to underestimate "the historical mediations and conditionalities of this experience of God" ${ }^{47}$ This remark explains the contradictory statements regarding the primary and respectively secondary character of mysticism. From a psychological point of view, it is an "original phenomenon" of all religion, but nevertheless the religious-mystical experience is in fact always mediated by tradition, and in this sense, its character is "secondary".

The same essay on the independence of religion enables us to illustrate the problem of the opposing evaluations of mysticism. In a rough historical [religionsgeschichtlich] formula, pantheist and theist mysticism are distinguished. The former was a phenomenon of decadence, a "vague and general longing for the Divine", as Troeltsch says elsewhere. ${ }^{48}$ The pantheist version of divinity had not understood that the spiritualization of the concept of God always also means a progress of morals [Versittlichung]. Therefore, it was necessary to draw a sharp distinction between pantheism and that mysticism "which is rooted in the sense of the infinite distance of the human soul and the divided and disrupted world from the unity and perfection of the divine being." 49 While pantheist mysticism often means a state of confusion, this does not apply for theist mysticism, which is ethically relevant and also plays a major role in Christianity.

At a later date, in particular in the "Social Doctrines", the concept of mysticism was further elaborated. Here, the distinction between practice and theory, between mysticism in the broader and in the narrower, "technical concentrated sense in which it is used in the philosophy of religion"50 is framed. Troeltsch distinguishes between the "insistence upon a direct inward and present religious experience" 51 and the theory regarding this immediacy, the communication between the divine and the human spirit. In the "Social Doctrines", Troeltsch outlines the type of mysticism as a general religious historical phenomenon, while the other two types, "church" and "sects" are described only against the background of the history of Christianity. ${ }^{52}$ Because of the breadth of the mysticism type, therefore, there seems to be little point in distinguishing

\footnotetext{
46 Troeltsch 1895-96, p. 413 (KGA I, S. 419).

47 Troeltsch 1895-96, p. 413 (KGA I, S. 419).

48 Troeltsch 1913 [1894], p. 270.

49 Troeltsch 1913 [1894], p. 187.

5o Troeltsch 1912a and Troeltsch 1931, p. 853 and p. 734

$5^{1} \quad$ Troeltsch 1912a and Troeltsch 1931, p. 850 and p. 730.

$5^{2}$ Only in rare exceptions, Troeltsch mentions Islamic and Jewish churches and sects; cf. Troeltsch 1922a, p. 15 and Troeltsch 1991 [1922], p. 219; Troeltsch 1912a and Troeltsch 1931, p. 375 , n. $165 \mathrm{~b}$ (this note was omitted in the translation).
} 
between a general and a specifically typological use of the concept of mysticism. One might however probably be able to distinguish a third form of mysticism besides Troeltsch's own distinction between mysticism in a broad sense $\left(\right.$ mysticism $\left.^{1}\right)$ and in a technical sense, or in the sense of the philosophy of religion $\left(\right.$ mysticism $^{2}$ ): the Christian or even Protestant form of mysticism ${ }^{2}$, for which the reference to Christian history and the person of Christ is constitutive $\left(\right.$ mysticism $\left.^{3}\right)$. In this last tradition, Troeltsch situates his own thought.

There is a tension between mysticism, which is oriented towards the suprahistorical on the one hand, and the historical and institutional aspects of a particular religion on the other hand. This problem cannot be fully elaborated in the present contribution, but will be discussed in the context of Troeltsch's ecclesiology. Troeltsch by no means ignored the tension between individualist mysticism and ecclesiastical institutions and traditions. Because of its spiritualist character, he called the History of Religion School [Religionsgeschichtliche Schule], which he was close to, ecclesiastically "impotent". This was a danger threatening his own undertaking, too, as he conceded. His theology therefore "seeks to make room for the historical element, and for the ritual and sociological factor which is bound up with it." 53 This is no easy task, as the "sociological antinomy between the claims of organization and those of the development of a free personality" 54 is difficult to overcome in the final analysis. This much is clear: you cannot build a stable organization on mysticism alone. This does not, however, mean that mysticism - in particular mysticism ${ }^{3}$ - had no sociological significance. Two aspects are underlined by Troeltsch. First mysticism means a communio sanctorum - an ideal, spiritual community - which Troeltsch speaks of warmly in several of his letters. ${ }^{55}$ Secondly, because of the

53 Troeltsch 1912a and Troeltsch 1931, p. 936, n. 504a and p. 985, n. 504a.

54 Troeltsch 1912a and Troeltsch 1931, p. 936, n. 504a and p. 985, n. 504a.

55 Cf. Troeltsch in a letter to Friedrich Heiler dated 28 June 1920 (about Heiler's loneliness as a Catholic, scientific theologian at a Protestant faculty), quoted from: Mitteilungen der Ernst-Troeltsch-Gesellschaft (8) 1994, pp. 283 et seq.: "I sometimes long for a communio sanctorum in which one might worship together. Only it does not exist, at least not visibly. So I congregate in worship every day with all members of the invisible church, at least for my phantasy and my soul [...]. So one is interdenominational then, and for the most practical, the most obvious things, one turns to the invisibly praying community of the spirit." [Ich sehne mich [...] manchmal nach einer communio sanctorum, in der man gemeinsam anbeten könnte. Allein Sie [sic!] ist wenigstens sichtbar nicht vorhanden. So sammle ich mich alle Tage mit allen Gliedern der unsichtbaren Kirche in der Anbetung 
general human instinct of fellowship as well as Christian-ethical theism, small groups of likeminded people may gather. Still, he says, the community-building force of mysticism is considerably weaker than the ones of the two other types.

According to Troeltsch, therefore, the institutions of the church form the basis for the necessary communication of Christian tradition. The churches will hold their ground "by their own historical weight". ${ }^{56}$ The subjectification of religion and the advanced religious plurality need to be factored in. To ensure this, the churches, which are built upon coercion and conformity, need to "become homes within which Christians of very varying outlooks can live and work together in peace. ${ }^{57}$ They should grant a maximum of freedom. ${ }^{58} \mathrm{As}$ a liberal theologian, Troeltsch believes in a separate but not isolated place of the churches in current life. He defended this ideal elsewhere under the title "elastic people's church". ${ }^{59}$ In principle, what is at stake is a "subjectification of churchdom and its means of unification". 60

Besides realistic arguments, Troeltsch also provides a religious reasoning for his position. Initially it looks as though he argued for a purely spiritualist conception of the church:

We need to understand the church as the community of the spirit of Christ [...], as an immense power which is our common spirit of life from which we all take our strength; in this manner, we do not assemble this

wenigstens für meine Phantasie u mein Gemüt [...]. Man ist dann eben überkonfessionell und hält sich fürs Praktische an das Nächstliegende, seelisch - menschlich an die unsichtbar betende Geistesgemeinde.].

$5^{6} \quad$ Troeltsch 1912a and Troeltsch 1931, p. 983 and p. 1010.

57 Troeltsch 1912a and Troeltsch 1931, pp. 982 et seq. and pp. 1009 et seq.

$5^{8}$ Cf. Troeltsch 1910a, 6. Thesis (KGA VI, p. 709): "Whatever way things may go in the future, in the present political and organisational state of religion, this individualism needs to be taken account of: 1) in deregulating the personal religious development of the clergy; 2) in deregulating religious self-determination of congregations; 3 ) in the manner of treating the audience in sermons and teaching; 4) in allowing and respecting full non-denominationality." [Welches der weitere Gang der Dinge auch sein mag, in dem gegenwärtigen religions-politischen und religiös-organisatorischen Zustande muß diesem Individualismus Rechnung getragen werden: 1. in der Freigebung der religiösen Persönlichkeitsbildung der Geistlichen, 2. in der Freigebung der religiösen Selbstbestimmung der Gemeinden, 3. in der Art der Behandlung der Zuhörer in Predigt und Unterricht, 4. in der Gestattung und Respektierung voller Konfessionslosigkeit.] Cf. on this subject Fechtner 1995. Fechtner underestimates the importance of mysticism for Troeltsch's - ecclesiological - position. He regards Troeltsch's religious ideal of community as a relatively frictionless negotiation of the types that integrates all aspects in itself, without grasping the foundations - and the involved problems - of this thought.

59 Troeltsch 1913 [1911a], pp. 104-108.

6o Troeltsch 1913 [1903], p. 439 (added in the volume of the collected works). 
community by our action and will, but experience it as the community of the spirit of Christ which transcends the single individual. It is the corpus mysticum Christi, which one has to feel as prior and superior to each single individual. If we form and school our feelings and thought in this self-evidence, then we will also consider it self-evident that the regional church must needs experience itself as an expression of the corpus mysticum Christi. ${ }^{61}$

This communal spirit, however, cannot be identified in particular organizations or objectifications. ${ }^{62}$ Then follows a decisive step in his argument. This inner spiritual effectiveness demands "the means of an objective preaching and the basis of a supra-individual [...] spiritual joint possession and thus the broad and comprehensive people's church." ${ }^{63}$ An essential requirement for a church is thus that grace is objectified and institutionalized. While this necessity of objectification is mentioned, its significance is downplayed in the context of this conception of the church with its strong spiritualist tendency, which is obvious, too, because within such a conception, the decisive moment of objectification, the necessity of an institution, cannot be satisfied. The choice of the institution cannot be explained on the basis of the mystical position alone.

Essentially, Troeltsch's thought concerns the interrelation between mysticism and institution. ${ }^{64}$ Mysticism is to be institutionalized by transforming the existing churches - which were originally oriented towards authoritarian mediation of salvation - into liberal institutions. On the basis of sociological as well as theological arguments, Troeltsch opts for an ecclesiology of the and.

61 Troeltsch 1913 [1911b], pp. 125 et seq. And such statements are no exception: cf. GS II, p. 129, p. 133; Troeltsch 1925, p. 3 .

62 Troeltsch 1913 [1911a], p. 106: "Such a spirit is in its essence independent of letter, dogma and law, it can only be recognized and judged by the spirit and therefore relies on a purely spiritual and inner effectiveness." [Ein solcher Geist ist seinem Wesen nach unabhängig von Buchstabe, Dogma und Recht, kann nur vom Geiste erkannt und gerichtet werden, ist darum auf eine rein geistige und innerliche Wirksamkeit angewiesen.]

63 Troeltsch 1913 [1911a], p. 106.

64 This also was the wish of Troeltsch's Catholic friend Friedrich von Hügel. Cf. von Hügel 1908, vol. 1, pp. vi et seq.: "I now wanted to try and get down to the driving forces of this [sc. mystical, ALM] kind of religion, and to discover in what way such a keen sense of, an absorption in, the Infinite can still find room for the Historical and Institutional elements of Religion, and, at the same time, for that noble concentration upon not directly religious contingent facts and happenings, and upon laws of causation or of growth, which constitutes the scientific temper of mind and its specific, irreplaceable duties and virtues." On Friedrich von Hügel cf. Neuner 1977. 
In order to hand down Christianity through the generations, the historical and the institutional cannot be dispensed with. Mysticism thus lives by preconditions that it cannot guarantee itself. This might be viewed as a lack of consistency in Troeltsch's position. On the other hand, this attempt at a synthesis of mysticism and institution may also be regarded as a well-considered acceptance of the situation of modern Christianity.

To conclude this section, I will add a brief remark on Troeltsch's rejection of the association model for religious communities. This model would contradict the Christian idea of grace "and thus the core of Christian religious thought." 65 This criticism of the association-type of Christianity of the sect, ${ }^{66}$ however, is basically a criticism of the individual-rational idea of enlightenment of society as a whole. In contrast, Troeltsch sees the first stirrings of a new sociology,

which, while it does not renew the old supernatural endowments and bonds, yet again brings to bear the priority of the whole before the individual, of the community before the members, of the communal spirit before the subjectivities, education before finished autonomy in its concepts of organic communal structures. ${ }^{67}$

This "organic" concept of community, according to Troeltsch, lends itself much better than the individualist concept of society to grasp the peculiarities of ecclesiastic institutions. The reference to a given - historical - power that does not arise from the composition of the individual wills of the members is constitutive for this conception of community. In Troeltsch's view, this conception of community should not lead to a relapse into a premodern phase because

65 Troeltsch 1912b, p. 1154.

66 Cf. Troeltsch 1907a, pp. 37 et seq. (KGA VI, pp. 386 et seq.): “Ultimately however, precisely from the religious point of view itself, such a division and destruction of religious joint ownership [sc. in sects and free churches, ALM], such a degradation of the handed-down inheritance to a concoction of always new declarations of will, this transformation of the great spiritual homeland into a lot of self-chosen associations with continuous joining and leaving is a heavy loss of old values and old securities in life after all." [Schließlich aber ist gerade vom religiösen Standpunkt selbst aus eine derartige Spaltung und Zertrümmerung des religiösen Gemeinbesitzes [sc. in Sekten und Freikirchen, ALM ], eine derartige Herabsetzung des mitgegebenen Erbes zu einem Gemächte jedesmal neuer Willenserklärungen, diese Verwandelung der großen geistigen Heimat in lauter selbstgewählte Vereine mit fortwährendem Aus- und Eintritt doch auch ein schwerer Verlust alter Lebenswerte und alter Lebenssicherheit.]

67 Troeltsch 1913 [1910], pp. 857 et seq. 
the individual is always conceived as actively participating in the formation of the communal spirit. ${ }^{6}$

There is little sense in approaching Troeltsch with a preconceived concept of "mysticism" and then either to dispute the mystical character of his oeuvre, or, inversely, to emphasize it. This would ultimately be a battle over words. As shown above, Troeltsch's theological position has to be considered as "mysticism" - in the broad sense of the word he himself used. In his opinion, the mystical theory of religion, which implies an identical core of communication of the human and the divine in all religious phenomena, is the basic assumption of modern religious studies and theology. Favouring mysticism was no coincidence, but for Troeltsch an expression of the ongoing transformation of modern religion. The slow but inexorable assertion of interiorization and subjectification makes the old sacramental conception of salvation intellectually, and increasingly also practically, obsolete. This development admittedly often implies a dissociation from Christian traditions and institutions. Nevertheless, the becoming-mystical of religion in the modern era does not ipso facto involve turning away from world and church. For Troeltsch, in contrast to Ritschl and his followers, mysticism means turning toward the world. He argues a - if you like - active, "ethical" form of mysticism which allows one to accomplish practical tasks "without losing one's inner peace". "There is a mysticism that is aloof from strife and yet actively leads to struggle and work and to community without completely exhausting itself in them." ${ }^{69}$ Regarded as an active principle, mysticism also - and to a much higher degree than Ritschl's social ethics with its focus on professional fidelity - implies distancing oneself from the contemporary constitution of church and state.

Troeltsch's position - from a theoretical perspective - means a criticism of the influential juxtaposition of ethical (active) and mythical (contemplative) religion, as introduced for instance by Max Weber. ${ }^{70}$ For Troeltsch, mysticism does not only mean to "have", but also to act: the individual is not only a vessel, but also a tool. This is the consequence of the position of a theist mysticism which presupposes an amalgamation of the human will with the

68 Cf. Troeltsch 1910b, p. 32 (KGA VI, p. 700): "Communal spirit and individual autonomy" can thus be combined in the concept of church. Cf. Molendijk 2013.

69 Troeltsch 1974, pp. 93 et seq. (letter dated 25 February 1912); Troeltsch, KGA, vol. 20, p. 512.

$70 \quad$ Weber 1988b [1920], pp. 538 et seq.; cf. Schluchter 1991, pp. 8off. 
divine will. Christian religion should not become a moralism with a religious angle, but, based on its mystical character, form the foundations for accomplishing practical tasks. In 1903, Nathan Söderblom had coined the term personality mysticism ['personlighetsmystik'] as opposed to infinitude mysticism ['onändlighetsmystik'] for this idea. ${ }^{71}$ As far as I know, this division has hardly caught on in Germany, but Troeltsch knew and approved of Söderblom's oeuvre. ${ }^{72}$

The subjective certainty of faith of being sheltered in the mystical community permits, according to Troeltsch, an active and critical commitment that is based on the ineluctable individual responsibility. The mystical position, however, does not provide guidelines to cope with practical matters. In this sense, it does not yield any effective social ethics - which was the conclusion of the "Social Doctrines". The problem of obtaining norms, according to Troeltsch, is the problem of modernity as such. The modern criticism of tradition and authority does not imply, however, that an autonomous reason could be "the creator of the whole reality and its values in a manner which is identical for everyone".73 Therefore, it is necessary to connect to tradition, which does not say anything regarding the relevant contents of tradition. For Troeltsch himself, however, there is no doubt that the basic elements of Christian tradition as he understood it were of the highest importance. The values of - mystically coloured - personalistic salvation religion - "the metaphysics of personalism which roots all values of personal life in God, and the ethics of the elevation of the person from being shackled to nature to the union with God."74 - form the ferment of Western culture. Ultimately, this is more important than any ecclesiastic institution, however important institutions may be. Based on this con-

71 Sharpe 1990, p. 112; cf. p. 158, pp. 168 et seq. Sharpe here refers to Söderblom 1903.

72 Cf however Troeltsch 1899 (Über Söderblom, Die Religion und die sociale Entwickelung. Freiburg im Breisgau 1898), p. 400 (KGA II, p. 542): Söderblom's treatise is characterized "by the none-too-common insight into the dual character of Christianity which, in a logical contradiction [! ALM], but in full practical compatibility, on the one hand focuses the souls for the higher world and insofar has a tendency toward ascetism and fleeing the world, but on the other hand has brotherly love to interest the minds in all human fortunes and in them being as useful to personal life as possible, and insofar has a tendency to keep the regulation of inner-worldly concerns in view." [durch eine nicht allzuhäufige Einsicht in den Doppelcharakter des Christenthums aus, das in logischem Widerspruch [! ALM], aber in voller praktischer Verträglichkeit einerseits die Gemüther für die obere Welt sammelt und insofern eine Tendenz zu Askese und Weltflucht besitzt, andererseits aber in der Bruderliebe die Gemüther an allen menschlichen Geschicken und an deren für das persönliche Leben möglichst dienlicher Gestalt interessirt und insofern eine Tendenz zur Sichtung innerweltlicher Lebensordnungen besitzt.]

73 Troeltsch 1907b, p. 208 (KGA VI, p. 532).

74 Troeltsch 1925 [1907], p. 330. 
viction, it also becomes clear why Troeltsch addresses the problem of culture and its religious dimension in his late oeuvre.

This does not however mean that mysticism disappears from his view. The starting point of his examinations of the philosophy of history is that one can step into the divine current of history, that rationality is based on "inner agreement with the basic direction of the divine will of life, which is intuitively grasped and intuited from history, tested and improved through comparison and in practical collisions." 75 This is a deep-rooted conviction. The world and the affairs of the world, according to Troeltsch, are held together "solely by the purpose of divine will". ${ }^{76}$ Accordingly, the "aim of the soul [is] participation in the infinite divine movement". ${ }^{77}$ Mysticism and ethics are directly linked because mysticism is not so much a "resting in God", but rather an active participation in divine will. Conscious mysticism therefore also means conscious ethics. Troeltsch's sober historical, sociological and history-philosophical work rests on his trust that the world is in God's hands. In the final passage of the "Social Doctrines", he says that the last goals of the world are "hidden" to us, but through human participation in the will of God it should be possible - according to the famous words of the historicism volume - "to overcome history with history". In this sense, mysticism is a basic category in the life and work of Ernst Troeltsch. You need not turn Catholic for this. The philosopher Eduard Spranger already noted in 1906 that this thought was a "conscious mysticism" "without which Troeltsch is justly unable to imagine any true religion." 78

\section{Biography}

Arie L. Molendijk is professor of the History of Christianity and Philosophy of Religion at the University of Groningen. He has published extensively in the history of ideas, in particular nineteenth- and twentieth-century theology, religious studies and philosophy. Among his writings are a German language book on the theologian and sociologist Ernst Troeltsch and a monograph The Emergence of the Science of Religion in the Netherlands (Brill, 2005).

Molendijk is also engaged in research on religion, identity and the public sphere, which led to a co-edited volume Exploring the Postsecular. The Religious,

75 Troeltsch 1922b, p. 187 (KGA XVI, p. 379).

76 Troeltsch 1925 [1917], here: p. 77.

77 Troeltsch 1925 [1917], here: p. 78.

78 Spranger 1906, p. 108. 
the Political and the Urban (Brill, 2010). Furthermore, he has participated in a research programme on new sacred places and emerging rituals, which resulted in two co-edited volumes Holy Ground. Re-inventing Ritual Space in Modern Western Culture (Peeters, 2010) and Sacred Places in Modern Western Culture (Peeters, 2011). His latest book is Friedrich Max Müller and the Sacred Books of the East (Oxford University Press, 2016).

\section{Bibliography}

Apfelbacher, Karl-Ernst: Frömmigkeit und Wissenschaft. Ernst Troeltsch und sein theologisches Programm. München/Paderborn/Wien: Schöningh 1978.

Apfelbacher, Karl-Ernst: “Ernst Troeltsch und die Mystik", in: Mitteilungen der ErnstTroeltsch-Gesellschaft 3 (1984), pp. 116-132.

Barth, Karl: Die Theologie Schleiermachers. Vorlesung Göttingen, Wintersemester 192324 (Barth Gesamtausgabe, Vol. 2). Zürich: Theologischer Verlag Zürich 1978.

Barth, Karl: Kirchliche Dogmatik, IV/ı. Zürich: Theologischer Verlag Zürich 1962.

Brunner, Emil: Die Mystik und das Wort. Der Gegensatz zwischen moderner Religionsauffassung und christlichem Glauben dargestellt an der Theologie Schleiermachers. Tübingen: J.C.B. Mohr ${ }^{2} 1928$.

Burdach, Konrad: "Die seelischen und geistigen Quellen der Renaissancebewegung", in: Historische Zeitschrift 149 (1934), pp. 477-521.

Diederichs, Eugen: Selbstzeugnisse und Briefe von Zeitgenossen. Ed. by Ulf Diederichs. Düsseldorf/Köln: Diederichs 1967.

Dilthey, Wilhelm: "Das Problem der Religion" (1911), in: idem: Die geistige Welt. Einleitung in die Philosophie des Lebens. Zweite Hälfte. Abhandlungen zur Poetik, Ethik und Pädagogik. Stuttgart/Göttingen: Vandenhoeck \& Ruprecht ${ }^{4}{ }_{1962}$, pp. $288-305$.

Elsas, Christoph: "Religion und Mystik in der deutschsprachigen protestantischen Diskussion", in: Ugo Bianchi (ed.): The Notion of "Religion" in Comparative Research. Selected Proceedings of the XVI. IAHR Congress. Roma: L'Erma di Bretschneider 1994, pp. 465-470.

Fechtner, Kristian: Volkskirche im neuzeitlichen Christentum. Die Bedeutung Ernst Troeltschs für eine künftige praktisch-theologische Theorie der Kirche. Gütersloh: Gütersloher Verlagshaus 1995 .

Fresenius, Wilhelm: Mystik und geschichtliche Religion. Eine systematische Untersuchung. Göttingen: Vandenhoeck \& Ruprecht 1912.

Graf, Friedrich Wilhelm: "Die ,kompetentesten' Gesprächspartner? Implizite Werturteile in Max Webers 'Protestantischer Ethik", in: Volkhard Krech/Hartmann Tyrell (ed.): Religionssoziologie um 19oo. Würzburg: Ergon 1995, pp. 209-248. 
Graf, Friedrich Wilhelm (ed.): "Ernst Troeltschs Briefe und Karten an Paul Wernle", in: Zeitschrift für Neuere Theologiegeschichte 2 (1/1995), pp. 85-147.

Harnack, Adolf von: Lehrbuch der Dogmengeschichte. Tübingen: J.C.B. Mohr ${ }^{4} 1910$.

Herrmann, Wilhelm: Der Verkehr des Christen mit Gott im Anschluß an Luther dargestellt. Stuttgart/Berlin: J. Cotta ${ }^{6} 1908$.

Hoffmann, Walther: "Mystik III:Neue Mystik", in:Religion in Geschichte und Gegenwart', Vol. 4. Tübingen: J.C.B. Mohr 1913, pp. 6o8-611.

Hübinger, Gangolf: "Kulturkritik und Kulturpolitik des Eugen-Diederichs-Verlags im Wilhelminismus. Auswege aus der Krise der Moderne”, in: Friedrich W. Graf/Horst Renz (ed.): Umstrittene Moderne. Die Zukunft der Neuzeit im Urteil der Epoche Ernst Troeltschs. Gütersloh: Mohn 1987, pp. 92-114.

Hübinger, Gangolf: Kulturprotestantismus und Politik. Zum Verhältnis vom Liberalismus und Protestantismus im wilhelminischen Deutschland. Tübingen: Mohr Siebeck 1994.

Hügel, Friedrich von: The Mystical Element of Religion, as Studied in Saint Catherine of Genoa and Her Friends. London/Göttingen: J. M. Dent 1908.

Klimek, Nicolaus: Der Begriff,Mystik' in der Theologie Karl Barths. Paderborn: Bonifatius 1990.

König, Christopher: Zwischen Kulturprotestantismus und völkischer Bewegung. Arthur Bonus (1864-1941) als religiöser Schriftsteller im wilhelminischen Kaiserreich. Tübingen: Mohr Siebeck 2018.

Luthardt, Christoph E.: Geschichte der christlichen Ethik, Vol. 2. Leipzig: Dörffling \& Franke Leipzig 1893 .

Maaß, Fritz-Dieter: Mystik im Gespräch. Materialien zur Mystik-Diskussion in der katholischen und evangelischen Theologie Deutschlands nach dem Ersten Weltkrieg. Würzburg: Echter-Verlag 1972.

Molendijk, Arie L.: Zwischen Theologie und Soziologie. Ernst Troeltschs Typen der christlichen Gemeinschaftsbildung. Kirche, Sekte, Mystik. Gütersloh: Gütersloher Verlagshaus 1996.

Molendijk, Arie L.: "Bewußte Mystik. Zur grundlegenden Bedeutung des Mystikbegriffs im Werk von Ernst Troeltsch”, in: Neue Zeitschrift für Systematische Theologie und Religionsphilosophie 41 (1/1999), pp. 39-61.

Molendijk, Arie L.: "Ernst Troeltsch über Friedrich Schleiermachers Auffassung von der Kirche", in: Ulrich Barth/Christian Danz/Wilhelm Gräb/Friedrich W. Graf (ed.): Die aufgeklärte Religion und ihre Probleme. Berlin: De Gruyter 2013, pp. 365-381.

Molendijk, Arie L.: "Church, Sect, Mysticism. Writing the History of Christianity", in: Christopher Adair-Toteff (ed.): The Anthem Companion to Ernst Troeltsch. London/ New York: Anthem Press 2018, pp. 55-70.

Neuner, Peter: Religiöse Erfahrung und geschichtliche Offenbarung. Friedrich von Hügels Grundlegung der Theologie. München/Paderborn/Wien: Schöningh 1977. 
Nipperdey, Thomas: Religion im Umbruch. Deutschland 1870-1918. München: C.H. Beck 1988.

Reischle, Max: Ein Wort zur Controverse über die Mystik in der Theologie. Freiburg im Breisgau: J.C.B. Mohr 1886.

Rendtorff, Trutz: “'Meine eigene Theologie ist sicherlich spiritualistisch'. Zur Funktion der 'Mystik' als Sozialform des modernen Christentums", in: Friedrich W. Graf/ Trutz Rendtorff (ed.): Ernst Troeltschs Soziallehren. Studien zu ihrer Interpretation. Gütersloh: Mohn 1993, pp. 178-192.

Ritschl, Albrecht: Die christliche Lehre von der Rechtfertigung und Versöhnung, Vol. 1. Bonn: Adolph Marcus 1870.

Ritschl, Albrecht: Geschichte des Pietismus, Vol. 1-3. Bonn: Adolph Marcus 1880-1886.

Ruddies, Hartmut: "Mystische Theologie? Bemerkungen zur Troeltsch-Interpretation Karl-Ernst Apfelbachers", in: Mitteilungen der Ernst-Troeltsch-Gesellschaft 2 (1983), pp. 95-108.

Schleiermacher, Friedrich: Über die Religion. Reden an die Gebildeten unter ihren Verächtern. In der Ausgabe von Rudolf Otto (1899). Vandenhoeck \& Ruprecht, Göttingen ${ }^{7} 1991$.

Scholz, Heinrich: "Mystik und geschichtliche Religion" (zu: W. Fresenius, Mystik und geschichtliche Religion), in: Deutsche Literaturzeitung 35 (1914), pp. 1925-1932.

Schluchter, Wolfgang: Religion und Lebensführung, Vol. II. Frankfurt am Main: Suhrkamp ${ }^{2} 1991$.

Sharpe, Eric J.: Nathan Söderblom and the Study of Religion. Chapel Hill/London: University of North Carolina Press 1990.

Simmel, Georg et al.: Verhandlungen des Ersten Deutschen Soziologentages vom 19.-22. Oktober 1910 in Frankfurt a.M. Reden und Vorträge. Tübingen: Mohr 1911.

Söderblom, Nathan: Uppenbarelsereligion: nagra synpunkter $i$ anledning af BabelBibeldiskussionen. Uppsala: Schultz 1903.

Spranger, Eduard: "Ernst Troeltsch als Religionsphilosoph", in: Philosophische Wochenschrift und Literaturzeitung 2 (1906), pp. 42-57, 69-80, 97-110.

Troeltsch, Ernst: "Die christlichen Weltanschauungen und ihre Gegenströmungen" (1894), in: Gesammelte Schriften, Vol. II. Tübingen: J.C.B. Mohr 1913, pp. 227-327.

Troeltsch, Ernst: “Die Selbständigkeit der Religion”, in: Zeitschrift für Theologie und Kirche (5) 1895, pp. 361-436, and (6) 1896, pp. 71-110, 167-218.

Troeltsch, Ernst: (Sammelrezension), in: Theologische Literaturzeitung (24) 1899, column 398-400.

Troeltsch, Ernst: “Theologie und Religionswissenschaft des 19. Jahrhunderts", in: Jahrbuch des freien Deutschen Hochstifts 1902, pp. 91-120.

Troeltsch, Ernst: "Theologie und Religionswissenschaft des 18. Jahrhunderts", in: Preußische Jahrbücher 114 (1903), pp. 30-56. 
Troeltsch, Ernst: “Was heißt 'Wesen des Christentums'?” (1903), in: Gesammelte Schriften, Vol. II. Tübingen: J.C.B. Mohr 1913, pp. 386-451.

Troeltsch, Ernst: "Protestantisches Christentum und Kirche in der Neuzeit" (1906, ${ }^{2}$ 1909), in: Hinneberg, Paul (Hg.): Geschichte der christlichen Religion (Die Kultur der Gegenwart, Teil I, Abteilung IV.i, 2. Hälfte), zweite stark vermehrte und verbesserte Auflage, zweiter Abdruck. Leipzig/Berlin: B.G. Teubner 1922, pp. 431-793.

Troeltsch, Ernst: Die Trennung von Staat und Kirche, der staatliche Religionsunterricht und die theologischen Fakultäten. Tübingen: J.C.B. Mohr 1907a.

Troeltsch, Ernst: "Autonomie und Rationalismus in der modernen Welt", in: Internationale Wochenschrift für Wissenschaft, Kunst und Technik 1 (1907b), pp. 199-210.

Troeltsch, Ernst: “Das Wesen des modernen Geistes" (1907), in: Gesammelte Schriften, Vol. IV. Tübingen: J.C.B. Mohr 1925, pp. 297-338.

Troeltsch, Ernst: "Wesen der Religion und der Religionswissenschaft" ( $\left.{ }^{2} 1909\right)$, in: Gesammelte Schriften, Vol. II. Tübingen: J.C.B. Mohr 1913, pp. 452-499.

Troeltsch, Ernst: "Religiöser Individualismus und Kirchen” [Thesen], in:Protestantische Monatshefte 14 (7/1910a), pp. 275 et seq.

Troeltsch, Ernst: "Schleiermacher und die Kirche", in:Martin Rade et al.: Schleiermacher der Philosoph des Glaubens. Sechs Aufsätze. Berlin: Buchverlag der Hilfe 191ob, pp. 9-35.

Troeltsch, Ernst: "Die Zukunftsmöglichkeiten des Christentums im Verhältnis zur modernen Philosophie" (1910), in: Gesammelte Schriften, Vol. II. Tübingen: J.C.B. Mohr 1913, pp. 837-862.

Troeltsch, Ernst: Die Bedeutung des Protestantismus für die Entstehung der modernen Welt. München/Berlin: R. Oldenbourg ${ }^{2} 1911$; Protestantism and Progress: A Historical Study of the Relation of Protestantism to the Modern World (first edition of the translation 1912). Boston: Beacon Hill 1958.

Troeltsch, Ernst: “Die Kirche im Leben der Gegenwart” (1911a), in: Gesammelte Schriften, Vol. II. Tübingen: J.C.B. Mohr 1913, pp. 91-108.

Troeltsch, Ernst: "Religiöser Individualismus und Kirche" (1911b), in: Gesammelte Schriften, Vol. II. Tübingen: J.C.B. Mohr 1913, pp. 109-133.

Troeltsch, Ernst: Die Soziallehren der christlichen Kirchen und Gruppen (Gesammelte Schriften, Vol. I). Tübingen: J.C.B. Mohr 1912a.

Troeltsch, Ernst: "Kirche", in: Religion in Geschichte und Gegenwart ${ }^{1}$, Vol. 3. Tübingen 1912b, column 1147-1152.

Troeltsch, Ernst: "Logos und Mythos in Theologie und Religionswissenschaft" (1913), in: Gesammelte Schriften, Vol. II. Tübingen: J.C.B. Mohr 1913, pp. 805-836.

Troeltsch, Ernst: "Das Neunzehnte Jahrhundert" (1913), in: Gesammelte Schriften, Vol. IV. Tübingen: J.C.B. Mohr 1925, pp. 614-649.

Troeltsch, Ernst: "Die alte Kirche" (1917), in: Gesammelte Schriften, Vol. IV. Tübingen: J.C.B. Mohr 1925, pp. 65-121. 
Troeltsch, Ernst: “Die Revolution in der Wissenschaft" (1921), in: Gesammelte Schriften,

Vol. IV. Tübingen: J.C.B. Mohr 1925, pp. 653-677.

Troeltsch, Ernst: Die Sozialphilosophie des Christentums. Gotha: L. Klotz 1922a.

Troeltsch, Ernst: Der Historismus und seine Probleme. Tübingen: J.C.B. Mohr 1922b.

Troeltsch, Ernst: "Meine Bücher" (1922), in: Gesammelte Schriften, Vol. IV. Tübingen: J.C.B. Mohr 1925, pp. 3-18.

Troeltsch, Ernst: Glaubenslehre. München/Leipzig: Duncker \& Humblot 1925.

Troeltsch, Ernst: Briefe an Friedrich von Hügel 1901-1923. Paderborn: Verlag BonifaciusDruckerei 1974.

Troeltsch, Ernst: Ernst Troeltsch Kritische Gesamtausgabe. Ed. by Friedrich Wilhelm Graf et al. Berlin/New York: De Gruyter 1998 etc. (Troeltsch KGA until October 2018 sixteen volumes were published).

Weber, Max: 'Kirchen' und 'Sekten' in Nordamerika. Eine kirchen- und sozialpolitische Skizze", in: Die Christliche Welt 20 (1906), (Nr. 24: 14.6.1906; Nr. 25: 21.6.1906), pp. $55^{8-562 ; 577-583 .}$

Weber, Max: "Die protestantischen Sekten und der Geist des Kapitalismus", in: idem: Gesammelte Aufsätze zur Religionssoziologie, Vol. 1. Tübingen: Mohr ${ }^{9} 1988$ a [1920], pp. 207-236.

Weber, Max: “Die Wirtschaftsethik der Weltreligionen”, in: idem: Gesammelte Aufsätze zur Religionssoziologie, Vol. 1. Tübingen: Mohr ${ }^{9} 1988$ b [1920], pp. 237-573.

Wernle, Paul: "Vorläufige Anmerkungen zu den Soziallehren der christlichen Kirchen undGruppen von Ernst Troeltsch", in: Zeitschrift für Theologie und Kirche 22 (1912), pp. 329-368 und 23 (1913), pp. 18-80.

Windelband, Wilhelm: Geschichte der neueren Philosophie: Leipzig: Breitkopf und Härtel ${ }^{3} 1904$.

Windelband, Wilhelm "Von der Mystik unserer Zeit" (1910), in: idem.: Präludien. Aufsätze und Reden zur Philosophie und ihrer Geschichte, Vol. 1. Tübingen: Mohr ${ }^{9} 1924$, pp. 290-299.

Windelband, Wilhelm Lehrbuch der Geschichte der Philosophie. Tübingen: Mohr ${ }^{15} 1980$.

Wyman, Walter E. Jr.: "Rez. von Apfelbacher, Frömmigkeit und Wissenschaft", in: Journal of Religion 60 (1980), pp. 353-355.

Zachhuber, Johannes: "Mysticism as a Social Type of Christianity? Ernst Troeltsch's Interpretation in its Historical and Systematic Context", in: Louise Nelstrop/ Simon D. Podmore (ed.): Exploring Lost Dimensions in Christian Mysticism. Burlington: Ashgate 2013, pp. 69-84.

\section{Translated by Brita Pohl}

